\title{
DEKRIMINALISERING NIE DIE ENIGSTE STRUIKELBLOK IN SEKSWERKERS SE STRYD OM ARBEIDSREGTE
}

\author{
Rinda Botha \\ BJuris LLB LLM LLD \\ Senior Lektor \\ Departement Straf- en Geneeskundige Reg \\ Universiteit van die Vrystaat \\ Hennie Oosthuizen \\ BJuris LLB LLD LLD \\ Professor en Hoof \\ Departement Straf- en Geneeskundige Reg \\ Universiteit van die Vrystaat
}

\section{SUMMARY}

Prostitution is at present still regarded as a criminal offence in South Africa. However, the possibility of the decriminalization of the sex trade enjoys serious consideration by the South African Law Commission. It is generally accepted that the position of sex workers (at present treated as illegal workers) regarding labour rights, will automatically improve with decriminalization. This article focuses mainly on whether indoor sex workers' access to labour rights will indeed improve. The risk for sex workers of being treated as independent contractors, once decriminalized, in the main enjoys attention and becomes clear from a comparative study with the Netherlands and Victoria (Australia) where sex work has been practised as a legal occupation for several years.

"They were not asking to be saved from prostitution, nor for the criminalization of brothel-keepers. They were asking to be recognized as women, mothers, civilians, but most of all as workers."

\footnotetext{
GroenLinks "GroenLinks's Position on Prostitution: Only Rights can Stop the Wrongs!" 2005 http://www.europeangreens.org/peopleandparties/wgroups/prostitution.pdf 2006-03-15) 
Sommiges verwys na prostitusie as dié oudste professie in die wêreld. ${ }^{2}$ Prostitusie (nou meer bekend as sekswerk) word egter tans steeds ingevolge artikel 20(1)(aA) van die Wet op Seksuele Misdrywe, ${ }^{3}$ soos onlangs gewysig deur die invoeging van subartikel $(1 \mathrm{~A}),{ }^{4}$ as misdaad in Suid-Afrika vervolg. Verpligte tronkstraf van tot drie jaar en 'n boete van tot R6 000 is moontlik vir hierdie oortreding. ${ }^{5}$ Sekswerk is dus 'n onwettige bedryf en sekswerkers beskik tans oor geen arbeidsregte nie.

Die Suid-Afrikaanse Regskommissie het onlangs 'n "Discussion Paper" uitgereik vir openbare kommentaar in hul ondersoek na die moontlike dekriminalisering van die seksbedryf. Die heroorweging van Suid-Afrika se huidige benadering tot sekswerk is 'n noodsaaklike gevolg van die uitspraak van die Grondwethof in die saak van Ellen Jordan en Twee Andere $v$ die Staat. ${ }^{7}$ Regter Ncgobo, verantwoordelik vir die meerderheidsuitspraak, het die grondwetlikheid van die voortbestaan van prostitusie en die aanhou van bordele as misdade bevestig, maar terselfdertyd genoem dat 'n groot gedeelte van die argumente en bewyse voor die hof gehandel het oor die vraag of die samelewing nie beter gedien kan word deur sekswerk te dekriminaliseer/wettig nie. Regter Ngcobo het daarop gewys dat dit die taak van die wetgewer en die regering is om sulke besluite te neem en nie dié van die howe nie. Sy taak was om oor die grondwetlikheid van die genoemde artikels te beslis en nie die wenslikheid daarvan nie. ${ }^{8}$ Die meerderheidsuitspraak het dus die voortbestaan van sekswerk in Suid-Afrika as misdaad verseker en terselfdertyd die weg gebaan vir 'n omvattende ondersoek na die effektiwiteit van die benadering tans deur Suid-Afrika gevolg.

Dit is nie te betwis dat die dekriminalisering van sekswerk in ' $n$ land ' $n$ rimpel-effek op vele ander terreine van die samelewing en ook die reg as sodanig kan toon nie. Hierdie artikel fokus op die effek van die dekriminalisering van die seksbedryf op die gebied van arbeidsreg. Die ondersoek word beperk tot die vraagstuk of die posisie van sekswerkers, verbonde aan bordele, se aanspraak op arbeidsregte in 'n gedekriminaliseerde seksbedryf inderdaad sal verbeter. Daar word veral gefokus op die moontlike risiko van die hantering van sekswerkers as onafhanklike kontrakteurs, indien gedekriminaliseer. Hierdie risiko blyk uit 'n

2 De Bruyn " $n$ Bespreking van die Vraagstuk of Prostitusie in Suid-Afrika Gedekriminaliseer Behoort te Word" 1996 9(2) Acta Criminologica 41.

323 van 1957.

4 Wysigingswet op die Strafreg (Seksuele misdrywe en verwante aangeleenthede) 32 van 2007. Die wysiging word bespreek in par 2 hieronder.

5 Artikel 22(a) van Wet op Seksuele Misdrywe 23 van 1957.

6 South African Law Reform Commission. Discussion Paper 0001/2009. Project 107 (Sexual Offences. Adult Prostitution).

20022 SACR 499 CC (CCT 31/01.)

8 Ellen Jordan en Twee Andere $v$ Die Staat supra 512 par 30. Sien ook Botha Die Ontwikkeling van en die Regsproblematiek in Verband met die Wettiging van Prostitusie in Suid-Afrika (2006) 47.

9 South African Law Reform Commission "Sexual Offences: Adult Prostitution Summary" Issue Paper 19, Project 107: 2002-09-03. Sien ook South African Law Reform Comission Discussion paper 0001/2009, Project 107 (Sexual Offences, Adult Prostitution). Sien verder Botha en Oosthuizen " $n$ Kritiese Evaluering van die Beleid ten opsigte van Prostitusie in Suid-Afrika en Alternatiewe vir die Toekoms" 2008 Obiter 410. 
vergelykende studie met Nederland en Victoria (Australië), waar sekswerk reeds 'n geruime tyd as wettige beroep bedryf word.

\section{DIE HUIDIGE POSISIE TEN OPSIGTE VAN SEKSWERK IN SUID-AFRIKA}

Suid-Afrika volg tans wat bekend staan as die voorkomingsbenadering. Volgens die voorkomingsbenadering word prostitusie as kriminele gedrag, waarvoor sekswerkers gestraf of gebiedend hervorm moet word, beskou. Alle aktiwiteite verbandhoudend met prostitusie en alle partye daarby betrokke se optrede word gekriminaliseer. ${ }^{10}$

Artikel 20(1)(aA) van die Wet op Seksuele Misdrywe 23 van 1957 het (voor wysiging) soos volg gelees:

"20. Persone wat van opbrengs van prostitusie leef of wat onsedelike dade pleeg of by die pleeg daarvan help.

(1) lemand wat -
(aA) ontug of 'n onsedelike daad met 'n ander persoon teen vergoeding pleeg;
is aan 'n misdryf skuldig."

Artikel $20(1)(a A)$ is onlangs gewysig deur die vervanging van subartikel $1(\mathrm{aA})$ en (b) met die subartikel (1A) van die Wysigingswet op die Strafreg (Seksuele Misdrywe en Verwante Aangeleenthede). ${ }^{11}$ Subartikel (1A) bepaal steeds dat ontug of 'n onsedelike daad met ' $n$ ander persoon teen vergoeding of die pleeg van 'n onsedelike daad met 'n ander in die openbaar ' $n$ misdaad is, maar slegs indien dit gepleeg word deur persone van 18 en ouer. Die enigste wysiging wat in effek ingetree het, is dus die ouderdomsbepaling wat bygevoeg is. Dit blyk dus dat dit die doel van die wysiging was om sekswerkers van 18 en jonger van strafregtelike vervolging te vrywaar.

Die Wysigingswet ${ }^{12}$ maak nou ook voorsiening vir die vervolging van sekswerkers se kliënte as daders ingevolge artikel 11 daarvan. Dit is waarskynlik 'n gevolg van die Grondwethof se minderheidsbeslissing in die saak Ellen Jordan en Twee Andere $v$ die Staat ${ }^{13}$ wat daarop gedui het dat die vervolging van kliënte in terme van artikel 20(1)(aA) as medepligtiges (en nie ook daders soos die sekswerkers self nie), op indirekte diskriminasie neerkom. ${ }^{14}$

10 GroenLinks $2005 \mathrm{http}: / /$ www.europeangreens.org/peopleandparties/wgroups/prostitution.pdf (nageslaan 2006-03-15). Sien ook Botha en Oosthuizen 2008 Obiter 412. Sien verder Botha 289.

1132 van 2007.

12 Ibid.

13 Supra.

14 Ellen Jordan en Twee Andere v Die Staat supra 524 par 63. Sien ook Botha en Oosthuizen 2008 Obiter 410. Sien verder Botha 70-72. 


\section{DIE EFFEK VAN DIE HUIDIGE BENADERING TEN OPSIGTE VAN SEKSWERKERS SE ARBEIDS- REGTE: DIE “KYLIE"-SAAK}

Soos reeds hierbo genoem, is sekswerk tans onwettig in Suid-Afrika. Die gevolg van die onwettige aard van sekswerkers se beroep op hul toegang tot arbeidsregte het onlangs in die saak van "Kylie" $v$ Van Zyl t/a Brigettes aandag geniet.

"Kylie" (skuilnaam) was werksaam as sekswerker by Brigittes, 'n masseursalon. Sy het 'n salaris ontvang en was veertien uur daagliks werksaam. Sy was op die perseel woonagtig en onderworpe aan streng kontroles en boetes. ${ }^{10}$ "Kylie" is op grond van beweerde dwelmmisbruik en wangedrag $^{17}$ ontslaan en het geen verhoor of geleentheid gehad om haarself te verdedig voor ontslag nie. ${ }^{18}$ Sy het die saak by die Kommissie vir Versoening, Bemiddeling en Arbitrasie (KVBA) gerapporteer. Die Kommissie het bevind dat 'n sekswerker nie as "werknemer" vir die doeleindes van die

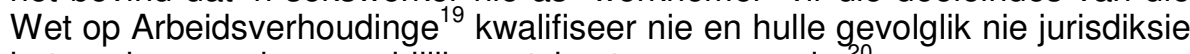
het om haar saak van onbillike ontslag te oorweeg nie.

Die Kommissaris het op die volgende oorwegings gewys as stawing vir haar bevinding dat "Kylie" se saak nie deur die KVBA aangehoor kon word nie: ${ }^{21}$

- Daar kan nie praktiese uitvoering aan 'n bevel van heraanstelling gegee word nie.

- Die uitbreiding van die Wet op Arbeidsverhoudinge, ${ }^{22}$ ten einde die werksaamhede van sekswerkers in te sluit, kan tot absurde gevolge aanleiding gee. Die sekswerker se weiering om 'n bevel van die werkgewer te gehoorsaam sal tog telkemale neerkom op die weiering om aan 'n onwettige bevel gehoor te gee.

5200728 ILJ 470 (CCMA).

16 Kylie and the Commission for Conciliation, Mediation and Arbitration, Commissioner Bella Goldman and Michelle van Zyl t/a Brigettes. Case no C52/07: par 5.

17 Sien verder LegalbriefTODAY "Sex workers don't have labour rights under Constitution" http://www.legalbrief.co.za (nageslaan 2008-08-01).

"On a substantive level the reasons alleged for dismissing her were:

A failure to do sufficient bookings;

exercising discretion or choice in terms of clients and conduct;

spending an hour in her room with her boyfriend who didn't pay;

hardly ever working on weekends;

failure to adhere to time, leading to discontent of other employees;

employer informed Kylie that she is still using drugs and made mention of the fact

that she refuses to do oral sex."

18 LegalbriefTODAY "Labour: Precedent-setting Case to be Heard Today" http://www.legal brief.co.za (nageslaan 2008-02-07).

1966 van 1995.

20 Bosch and Christie "Are Sex Workers 'Employees'?" 200728 ILJ 804. Sien ook Van Jaarsveld "'n Arbeidsregtelike Perspektief op die Ongure Kontrak van Kylie" 200972 THRHR 467.

21 Bosch and Christie 200728 ILJ 804-805.

2266 van 1995. 
- Alhoewel prostitusie openlik bedryf word, die KVBA verplig is om strafregtelike bepalings te eerbiedig.

Die saak is hierna vir hersiening na die Arbeidshof in Kaapstad verwys.

Regter Cheadle van die Arbeidshof het "Kylie" se appèl van die hand gewys op grond van die volgende redes: ${ }^{23}$

- Prostitusie word verbied ingevolge die Wet op Seksuele Misdrywe 23 van $1957 ;^{24}$

- daar is ' $n$ fundamentele stelreël in ons reg dat howe nie veronderstel is om onwettige bedrywighede goed te keur of aan te moedig nie $;^{25}$

- hierdie stelreël is ook van toepassing op statutêre regte; ${ }^{26}$

- die toepassing van hierdie stelreël het tot gevolg dat sekswerkers nie 'n afdwingbare statutêre reg tot billike ontslag ingevolge die Wet op Arbeidsverhoudinge geniet nie,;7

- die appellant se eis vir skadevergoeding gebaseer op die reg tot billike ontslag is dus onafdwingbaar.

Regter Cheadle het pertinent genoem dat die beslissing nie geïnterpreteer moet word asof 'n sekswerker nie 'n werknemer vir doeleindes van die Wet op Arbeidsverhoudinge kwalifiseer nie, maar slegs dat die KVBA en die Arbeidshof nie die statutêre reg tot billike ontslag kan afdwing nie. ${ }^{29}$ Dit sal onwettige bedrywighede aanmoedig en goedkeur. Die beslissing dui ook nie daarop dat sekswerkers nie beskerming ingevolge ander arbeidswetgewing soos die Wet op Basiese Diensvoorwaardes, ${ }^{30}$ Wet op Beroepsgesondheid en Veiligheid, ${ }^{31}$ Wet op Vergoeding vir Beroepsbeserings en Siektes, ${ }^{32}$ en Werkloosheidversekeringswet ${ }^{33}$ geniet nie. Sekswerkers se aanspraak op hierdie regte en voordele moet op individuele basis beoordeel word teen die agtergrond of die afdwinging daarvan georganiseerde sekswerk sal aanmoedig en/of goedkeur of nie. ${ }^{34}$ Dit is inderdaad moeilik om aan ' $n$

23 Kylie and the Commission for Conciliation, Mediation and Arbitration, Commissioner Bella Goldman and Michelle van Zyl t/a Brigettes. Case no C52/07 par 5.

24 Kylie and the Commission for Conciliation, Mediation and Arbitration, Commissioner Bella Goldman and Michelle van Zyl t/a Brigettes. Case no C52/07 par 3.1.

25 Kylie and the Commission for Conciliation, Mediation and Arbitration, Commissioner Bella Goldman and Michelle van Zyl t/a Brigettes. Case no C52/07 par 3.2.

26 Kylie and the Commission for Conciliation, Mediation and Arbitration, Commissioner Bella Goldman and Michelle van Zyl t/a Brigettes. Case no C52/07 par 3.3.

27 Kylie and the Commission for Conciliation, Mediation and Arbitration, Commissioner Bella Goldman and Michelle van Zyl t/a Brigettes. Case no C52/07 par 3.4.

28 Kylie and the Commission for Conciliation, Mediation and Arbitration, Commissioner Bella Goldman and Michelle van Zyl t/a Brigettes. Case no C52/07 par 3.7.

29 Kylie and the Commission for Conciliation, Mediation and Arbitration, Commissioner Bella Goldman and Michelle van Zyl t/a Brigettes. Case no C52/07 par 4.

3075 van 1997.

3185 van 1993.

32130 van 1993.

3363 van 2001.

34 Kylie and the Commission for Conciliation, Mediation and Arbitration, Commissioner Bella Goldman and Michelle van Zyl t/a Brigettes. Case no C52/07 par 4. 
voorbeeld te dink waar die toestaan van so 'n statutêre reg of voordeel sekswerk nie sal aanmoedig of ten minste goedkeur nie.

Die uitspraak van die Arbeidshof dien nou as gesag daarvoor dat, alhoewel sekswerkers as werknemers mag kwalifiseer in terme van die Wet op Arbeidsverhoudinge, hulle statutêre regte daarin vervat, onafdwingbaar is weens die onwettige aard van hul beroep. ${ }^{35}$ Die dekriminalisering van die seksbedryf blyk dus 'n verandering op die gebied te kan meebring.

Die "Kylie"-saak is intussen na die Grondwethof verwys en die uitslag daarvan was nog onbekend tydens die skryf van die artikel. ${ }^{36}$

\section{SEKSWERKERS: WERKNEMERS OF ONAFHANK- LIKE KONTRAKTEURS?}

Sou die seksbedryf gedekriminaliseer word, bestaan die risiko steeds dat sekswerkers verbonde aan bordele as onafhanklike kontrakteurs eerder as werknemers hanteer kan word. Die arbeidsregte, soos in die meeste arbeidswetgewing $^{37}$ uiteengesit, is egter slegs op werknemers en nie ook op onafhanklike kontrakteurs nie, van toepassing. Sou sekswerkers dus na die dekriminalisering van die seksbedryf as onafhanklike kontrakteurs hanteer word, sal dekriminalisering op die gebied van arbeidsreg ' $n$ waardelose triomftog wees! Sekswerkers sal steeds nie beskerming wat deur arbeidswetgewing gebied word, geniet nie en bordeel-eienaars sal gevrywaar wees van verpligtinge wat van werkgewers verwag kan word. Juis om hierdie rede geniet die onderskeid tussen werknemer en onafhanklike kontrakteur kortliks aandag.

\section{Die onderskeid tussen werknemer en onafhanklike kontrakteur}

Die onderskeid tussen werknemer en onafhanklike kontrakteur het vanweë die gevolge daaraan verbonde reeds baie aandag in Suid-Afrika geniet. Soveel so dat Suid-Afrika in die verlede reeds van drie toetse gebruik gemaak het om te bepaal of 'n persoon inderdaad 'n werknemer of onafhanklike kontrakteur is. Ten einde hierdie onderskeid te tref sal die

35 Sien ook Grogan "Of Prostitutes and Foreigners: Invalid Contracts and the LRA" Des 2008 Employment Law 15 in dié verband.

"In 'Kylie', the court reasoned as follows:

While 'everybody' is entitled to fair labour practices and prostitutes are entitled to protection under the Constitution as persons, it does not follow that they are entitled to constitutional protection as employees. This is because the main principle underlying the Constitution is the doctrine of legality, a by-product of which is that the courts must not sanction illegal activity. In line with that principle, the courts have always declined to enforce immoral or illegal contracts."

36 "Sapa" Vrydag 22 Aug 2008 The Citizen. Sien verder "News Worth Knowing" Dinsdag 26 Aug 2008 BusinessDay.

37 Wet op Arbeidsverhoudinge 66/1995: Artikel 213; Wet op Basiese Dienvoorwaardes 75 van 1997: sien artikel 3 en die definisie van werknemer in artikel 1; Wet op Vergoeding vir Beroepsbeserings en Siektes 130/1993:sien artikel 22 en die definisie van werknemer; Werkloosheidversekeringswet 63/2001: sien artikel 2 en die definisie van werknemer. 
definisie van 'n werknemer ingevolge die Wet op Arbeidsverhoudinge ${ }^{38}$ asook die toetse aangewend in die verlede om vas te stel of 'n persoon inderdaad 'n werknemer is, kortliks aandag geniet.

'n Statutêre vermoede oor wie ' $n$ werknemer is, word tans aangetref in artikel 200A van die Wet op Arbeidsverhoudinge ${ }^{39}$ en lees soos volg:

"(1) Totdat die teendeel bewys is, word daar vermoed dat 'n persoon wat werk vir, of dienste lewer aan, enige ander persoon, ongeag die vorm van die kontrak, 'n werknemer is, indien een of meer van die volgende faktore aanwesig is:

(a) die wyse waarop die persoon werk, is onderhewig aan die beheer of leiding van ' $n$ ander persoon;

(b) die persoon se werksure is onderhewig aan die beheer of leiding van 'n ander persoon;

(c) in die geval van 'n persoon wat vir 'n organisasie werk, maak die persoon deel van daardie organisasie uit;

(d) die persoon het oor die afgelope drie maande gemiddeld minstens 40 uur per maand vir daardie persoon gewerk;

(e) die persoon is ekonomies afhanklik van die ander persoon vir wie hy of sy werk of dienste lewer;

(f) die persoon word deur die ander persoon van bedryfsgereedskap of werktoerusting voorsien; of

(g) die persoon werk vir of lewer dienste aan net een persoon."

Voor die inwerkingtreding van artikel 200A is die onderskeid tussen werknemer en onafhanklike kontrakteur hoofsaaklik deur middel van drie onderskeie toetse bepaal, naamlik:

- Die Kontrole-toets, wat gefokus het op die element van kontrole wat deur die werkgewer oor die werknemer uitgeoefen is. Die mag van kontrole is tradisioneel beskou as die kenteken van 'n dienskontrak.

- Die Organisasie-toets, waarvolgens 'n kontrak as 'n dienskontrak beskou is indien 'n persoon as deel van die sakeonderneming aangestel is en indien sy werk gedoen is as geïntegreerde deel van die sakeonderneming. Hierdie toets is later deur die Appèlhof verwerp omrede dit tot meer vrae as antwoorde aanleiding gegee het. ${ }^{41}$

- Asook die Dominante-Indruk-toets, waarvolgens die howe die bestaan van 'n dienskontrak benader het deur die verhouding in geheel te beskou en 'n afleiding van die algehele prentjie te maak. ${ }^{42}$

In SA Broadcasting Corporation v Mckenzie ${ }^{43}$ het die Arbeidsappèlhof die vernaamste verskille tussen ' $n$ dienskontrak en ' $n$ kontrak met 'n onafhanklike kontrakteur uiteengesit.

Die verskille kan as volg saamgevat word: ${ }^{44}$

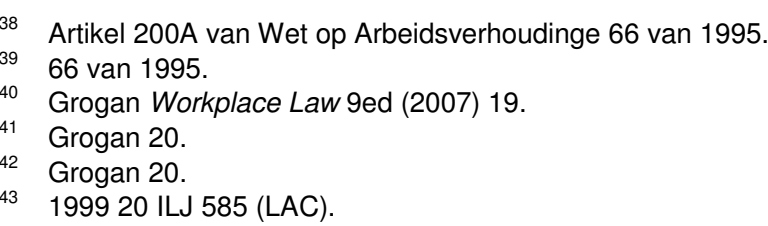


Kenmerke van 'n dienskontrak (bestaan van 'n werkgewer-werknemerverhouding):

- Die doel is die lewering van persoonlike diens tussen werkgewer en werknemer.

- Die werknemer lewer die diens op bevel van die werkgewer.

- Die werkgewer mag besluit of hy wil hê dat die werknemer diens moet verrig.

- Die werknemer is verplig om wettige en redelike instruksies in verband met die werk wat gedoen moet word en die manier hoe dit gedoen moet word te gehoorsaam.

- Dit word beëindig deur die dood van die werknemer.

- Dit kan beëindig word teen die einde van 'n ooreengekome tydperk.

Kenmerke van 'n kontrak met 'n onafhanklike kontrakteur:

- Die objek is die produksie van 'n spesifieke diens of die produksie van 'n spesifieke resultaat.

- 'n Onafhanklike kontrakteur is nie verplig om die diens persoonlik te verrig nie, tensy anders ooreengekom.

- 'n Onafhanklike kontrakteur is verplig om spesifieke werk of 'n spesifieke resultaat binne 'n redelike tyd te voltooi.

- 'n Onafhanklike kontrakteur is nie verplig om instruksies rakende die manier hoe die werk uitgeoefen moet word te gehoorsaam nie.

- Dit word nie beëindig deur die dood van die onafhanklike kontrakteur nie.

- Dit word beëindig na afhandeling van die spesifieke werk of die produksie van 'n spesifieke resultaat.

Die Arbeidsappèlhof het aanvaar dat die "dominante indruk" wat deur die ooreenkoms en werksverhouding gelaat word die finale bepaler van die aard en gevolge van die verhouding is.

\section{Dienste verrig deur sekswerkers in bordele aan- duidend van 'n werkgewer-werknemer-verhouding}

De Villiers ${ }^{46}$ wys daarop dat sekswerkers verbonde aan masseersalonne, gesellin-agentskappe en bordele, dikwels deur bestuurders en eienaars as onafhanklike kontrakteurs hanteer word. Die meeste sekswerkers verbonde aan bordele is egter werknemers. ${ }^{47}$

\footnotetext{
Grogan 22.

Grogan Workplace Law 7ed 200317.

46 Augustus 2001 Weekly Mail \& Guardian 24.

47 lbid.
} 
Die feit dat hierdie sekswerkers wel werknemers is, blyk uit die volgende: 48

- Indien 'n sekswerker werk kry, trek sy gewoonlik na die perseel toe.

- Die bordeel-eienaar betaal die huur en onderhou die eiendom.

- Skofte word deur die eienaar of bestuurder bepaal.

- Sekswerkers is nie gemagtig om die perseel gedurende skofte te verlaat nie.

- Skofte duur gewoonlik tussen 12 en 14 uur.

- In baie bordele word die tarief deur die bordeel bepaal.

- Die sekswerker word deur die kliënt betaal, trek haar gedeelte af en oorhandig die balans onmiddellik aan die bestuur. (Sekswerkers hou gewoonlik sowat $40 \%-60 \%$ van die geld wat deur die kliënte betaal word).

- Boetes wat tussen R5 tot R1 000 wissel word dikwels afgetrek vir die verbreking van sogenaamde "huisreëls".

Met die kenmerke van 'n dienskontrak soos uiteengesit ingevolge die "dominante-indruk-toets" in SA Broadcasting Corporation v Mckenzie ${ }^{49}$ en die vermoede oor wie 'n werknemer is ingevolge artikel 200A van die Wet op Arbeidsverhoudinge $^{50}$ vars in die geheue, is dit duidelik dat hierdie sekswerkers, indien die seksbedryf gedekriminaliseer word, as werknemers eerder as onafhanklike kontrakteurs hanteer moet word. Weekes ${ }^{51}$ wys egter daarop dat baie sekswerkers kontrakte teken wat hulle as onafhanklike kontrakteurs bestempel. Terwyl onafhanklike kontrakteurs die voorreg het om te kies watter werk hul wil verrig en wanneer, word hierdie sekswerkers wat aangestel is as "onafhanklike kontrakteurs", eerder as werknemers hanteer. Werkgewers het beheer oor hul werksure, hul reg om kliënte te weier asook oor die bedrag geld wat hulle vir dienste mag vra. Tans is sekswerkers in Suid-Afrika egter nie in die posisie om op arbeidsregte as werknemers aan te dring nie, soos blyk uit die "Kylie-saak". Hierdie wanvoorstelling van seks-werkers as "onafhanklike kontrakteurs" kan dus nie aangespreek word nie.

\section{DIE POSISIE IN NEDERLAND}

In die jaar 2000 is die bordeelverbod van 1911 in Nederland ingevolge die Wet Opheffing Bordeelverbod van 2000 opgehef. $^{52}$ Dit is tans wettig om ' $n$

48 De Villiers 9 Augustus 2001 Weekly Mail \& Guardian 24. Sien verder Weekes March/April 2006 South African Labour Bulletin Vol 30(1) 16: "Research with indoor sex workers in Cape Town revealed that employers fine workers as much as R1 000 for coming a few minutes late to work, force workers not to leave the premises and charge high fees for the use of rooms. They also force workers to work excessively long shifts, even 24 hour shifts, and sometimes prevent them from accessing basic health and safety equipment."

52 Sien Pakes "Tolerance and Pragmatism in the Netherlands: Euthanasia, Coffeeshops and Prostitution in the 'Purple Years'” 1994-2002 Vol 5(4) International Journal of Police Science \& Management 223. 
bordeel te bestuur en die prostitusie van volwassenes te organiseer indien dit met beide partye se toestemming plaasvind. ${ }^{53}$

Bordele word in sekere areas toegelaat en moet aan plaaslike regulasies voldoen. In 2002 het die meeste munisipaliteite van Nederland reeds 'n lisensiëringstelsel vir bordele opgestel ingevolge waarvan wettige werknemers en veiligheidsmaatreëls vereis word. ${ }^{54}$ Bordele, onderworpe aan ' $n$ lisensiëringstelsel by wyse van ' $n$ stadsordonnansie, moet aan sekere standaarde voldoen wat betref stadsbeplanning, higiëne, brandveiligheid en bestuur. As daar nie aan hierdie standaarde voldoen word nie, sal die bordeel uiteindelik gesluit word deur administratiefregtelike stappe wat 'n makliker en meer effektiewe prosedure van vervolging is as in die geval van die vervolging van koppelary.

\section{Sekswerkers se posisie in praktyk: Werknemer of onafhanklike kontrakteur?}

Artikel 7:610 van die "Civil Code" sit die karaktereienskappe vir die bestaan van 'n dienskontrak in Nederland soos volg uiteen:

"(i) the employee is obliged to work for a certain time,

(ii) the employer is obliged to pay wages, and

(iii) the employee performs his/her duty in the service of the employer."

In 1999 is 'n nuwe bepaling, (artikel 7:610(a)) bygevoeg. Artikel 7:610 (a) lees soos volg:

"Any person who for the benefit of another person performs work for remuneration by that other person for three consecutive months weekly or for no fewer than 20 hours per month, is presumed to perform such work pursuant to a contract of employment."

Met die opheffing van die bordeelverbod in die jaar 2000 is daar algemeen aanvaar dat bordeel-eienaars in die seksbedryf nou onderworpe is aan arbeidswetgewing en maatskaplike versekering en belasting moet betaal. ${ }^{56}$ Dit blyk egter nie die geval in die praktyk te wees nie. ${ }^{57}$ Die meeste bordeel-eienaars is steeds onwillig om dienskontrakte met sekswerkers te sluit. Bordeel-eienaars argumenteer dat hul slegs ondersteuningsdienste aan sekswerkers verskaf en daarom nie verplig is om belasting of maatskaplike versekeringsbydraes aan die owerheid te betaal nie..$^{58}$ Volgens navorsing ${ }^{59}$ word ongeveer $95 \%$ van die sekswerkers in die gelisensieerde

53 Wijers "Prostitution Policies in the Netherlands" May 2008 sine pagina http://sexworkeurope.org/icrse/images/phocadownload/Wijers M Pros policies NL 2008.pdf.

54 Outshoorn "Pragmatism in the Polder: Changing Prostitution Policy in The Netherlands 2004 12(2) Journal of Contemporary European Studies 172.

55 GroenLinks $2005 \mathrm{http}: / /$ www.europeangreens.org/peopleandparties/wgroups/prostitution.pdf (nageslaan 2006-03-15).

56 Outshoorn 2004 12(2) Journal of Contemporary European Studies 165.

57 Marjan Wijers "Prostitution Policies in the Netherlands" May 2008 sine pagina http://sexworkeurope.org/icrse/images/phocadownload/Wijers M Pros policies NL 2008.pdf.

58 www.minbuza.nl/english. Publication of the Netherlands Ministry of foreign affairs; Dutch Policy on Prostitution; Questions and Answers 2005:3.

59 Daalder Prostitution in the Netherlands since the Lifting of the Brothel Ban 2007 64-65. 
sektor steeds as onafhanklike kontrakteurs beskou, alhoewel die verhouding tussen die sekswerkers en eienaars van sakeondernemings eerder aanduidend is van die bestaan van 'n werkgewer-werknemer-verhouding. Meer as driekwart van die 354 sekswerkers werksaam in die gelisensieerde sektor het aangedui dat hulle ' $n$ mondelinge ooreenkoms met die eienaar van die sakeonderneming gehad het wat betref werksure, betaal van huur, pryse vir dienste gelewer en vergoeding. ${ }^{60}$ Indien daar nie aan laasgenoemde gehoor gegee is nie, is sekswerkers soms van die perseel verban. ${ }^{61}$ Dit is alles aanduidend van die bestaan van ' $n$ werkgewerwerknemer-verhouding.

Die owerheid kan wel hier waar die seksbedryf wettig is, die werklike aard van die werksverhouding verifieer en teen sakeondernemings wat onder vals voorwendsels funksioneer, optree. ${ }^{62}$

Heelwat hofsake ${ }^{63}$ het al plaasgevind waarin die vraagstuk na die tipe werksverhouding wat tussen 'n sakeonderneming en sekswerker bestaan, na vore gekom het. Die verrigtinge is ingestel deur bordeel-eienaars teenoor die Employee Insurance Implementing body and/or the Tax Administration. ${ }^{64}$ Die bordeel-eienaars het ontken dat die objektiewe karaktereienskappe wat vereis word vir die vermoede van die bestaan van 'n werkgewer-werknemerverhouding, aan voldoen word. In 9 van die 12 hofsake was die voorsittende regters egter van mening dat die werksomstandighede aanduidend was daarvan dat die sekswerker inderdaad 'n werknemer was. ${ }^{65}$ In die sake waarteen appèl aangeteken is, het die "Central Appeal Council" die bevinding van die regters bekragtig en sodoende bevestig dat die verhouding tussen 'n bordeel-eienaar en een of meer sekswerkers, werksaam in die besigheid, as 'n werkgewer-werknemer-verhouding geag moet word ooreenkomstig artikel 7:610 van die "Civil Code". ${ }^{66}$

Alhoewel daar dus tog vordering op die gebied van sekswerkers se toegang tot arbeidsregte in Nederland waargeneem kan word, het die dekriminalisering van prostitusie en opheffing van die bordeelverbod nie onmiddellike verligting en duidelikheid op die gebied van arbeidsregte gebring nie. ${ }^{67}$ Die meerderheid-gesag ${ }^{68}$ is egter aanduidend daarvan dat die

60 Daalder 65

61 Ibid.

62 www.minbuza.nl/english. Publication of the Netherlands Ministry of foreign affairs; Dutch Policy on Prostitution; Questions and Answers 2005:3.

63 Hof Amsterdam 8 september 2005, PO3/02264; Rb. Rotterdam 30 december 2004 , PREMIE 03F3385.ZWI; Rb. Groningen 17 januari 2005, AWB 03/986; rb. 's-Hertogenbosch 27 mei 2005, AWB 03/2457; Rb.'s-Hertogenbosch 2 juni 2005, AWB 04/108, ab 04/235; Rb. Utrecht 11 juli 2005, rolnr. SBR 04/344; CRvB 5 januari 2006, AWB 05/1391 ALGEM; Rb. 's-Hertogenbosch zp. Maastricht, 24 november 2005 AWB 05/1082 ALGEM; Rb.'sHertogenbosch, 17 maart 2006 AWB 04/3031. 'n Bespreking van die hofsake geniet aandag in die studie deur Zuidema et al Mededeling van het Hugo Sinzheimer Instituut 14,"Arbeidsrecht voor prostitutes? De (on)mogelijkheid van toepassing van het arbeidsrecht op arbeidsverhoudingen in de Prostitutiebranche", Hugo Sinzheimer Institute 2006, . slegs beskikbaar in Nederlands.

64 Daalder 62.

65 Ibid.

66 Ibid.

67 Sien ook Marjan Wijers "Prostitution Policies in the Netherlands" May 2008 sine pagina http://sexworkeurope.org/icrse/images/phocadownload/Wijers M Pros policies NL 2008.pdf. 
verhouding tussen 'n sekswerker en bordeel-eienaar in 'n gedekriminaliseerde seksbedryf as dié van ' $n$ werkgewer-werknemer beskou moet word en sekswerkers die beskerming van arbeidswetgewing behoort te geniet.

\section{DIE POSISIE IN VICTORIA (AUSTRALIË)}

Prostitusie word deur verskeie wette ${ }^{69}$ in sommige dele van Australië gereguleer. ${ }^{70}$ Die posisie in Victoria word bespreek omrede sekswerk reeds 'n geruime tyd hier as beroep bedryf word.

Die hoofmeganisme wat gebruik word om prostitusie in Victoria te reguleer is die "Prostitution Control Act" van 1994 (hierna genoem die Wet) wat op 13 Junie 1995 in werking getree het. ${ }^{71}$ Regulasies is te vinde in hierdie wetgewing asook die "Health Act" van 1958 oor hoe seksdienste in Victoria verskaf moet word. ${ }^{72}$ Een van die maniere waarmee die Wet poog om prostitusie in Victoria te beheer is die skepping van ' $n$ gelisensieerde sisteem vir bedrywers van seksuele dienste asook vir mense wat hierdie dienste bestuur indien die verskaffer nie op die perseel teenwoordig is nie. Lisensiëring vind plaas deur die "Business Licensing Authority" wat onder andere daarna kyk of die aansoeker die nodige maatreëls wat die veiligheid van persone werksaam in die sakeonderneming betref in plek het. ${ }^{73}$

Die regulering van wettige sekswerk ingevolge die Wet word gekomplementeer deur 'n uitgebreide stel regulasies soos vervat in die "Prostitution Control Regulations" van 1995 (soos daargestel deur die Wet), en die "Health (Infectious Disease) Regulations" van 2001, soos daargestel deur die "Health Act". Regulasie 19 van die "Prostitution Control Regulations" spesifiseer veiligheidsvereistes wat nagekom moet word deur gelisensieerde operateurs van sekswerk. Dit sluit onder andere die verbod op 'n gelisensieerde operateur se reg om 'n sekswerker se besluit om nie 'n seksuele diens aan 'n kliënt te veskaf nie omrede dit gewelddadig of onveilig is, in. ${ }^{74}$

68 Hof Amsterdam 8 september 2005, PO3/02264; Rb. Rotterdam 30 december 2004, PREMIE 03F3385.ZWI; Rb. Groningen 17 januari 2005, AWB 03/986; rb.'s-Hertogenbosch 27 mei 2005, AWB 03/2457; Rb.'s-Hertogenbosch 2 juni 2005, AWB 04/108, ab 04/235; Rb. Utrecht 11 juli 2005, rolnr. SBR 04/344; CRvB 5 januari 2006, AWB 05/1391 ALGEM; Rb.'sHertogenbosch zp. Maastricht, 24 november 2005 AWB 05/1082 ALGEM; Rb.'sHertogenbosch, 17 maart 2006 AWB 04/3031. 'n Bespreking van die hofsake geniet aandag in die studie deur Zuidema et al Mededeling van het Hugo Sinzheimer Instituut 14,"Arbeidsrecht voor prostitutes? De (on)mogelijkheid van toepassing van het arbeidsrecht op arbeidsverhoudingen in de Prostitutiebranche", Hugo Sinzheimer Institute 2006, Universiteit van Amsterdam - slegs beskikbaar in Nederlands.

69 Victoria - Die "Prostitution Control Act" van 1994

Queensland - Die "Prostitution Act" van 1999.

Nieu-Suid Wallis - "Disorderly Houses Act" van 1943 soos gewysig.

70 Murray "Labour Regulation in the Legal Sex Industry" 200316 Australian Journal of Labour Law 2-3.

1 Murray 200316 Australian Journal of Labour Law 7.

72 Murray 200316 Australian Journal of Labour Law 7-8.

73 Murray 200316 Australian Journal of Labour Law 8-9.

74 Murray 200316 Australian Journal of Labour Law 12-13. 


\section{Sekswerkers se posisie in die praktyk: werknemer of onafhanklike kontrakteur?}

Ook in Australië is die gemeenregtelike onderskeid tussen werknemer en onafhanklike kontrakteur van groot belang omrede eersgenoemde beskerming van arbeidswetgewing geniet, terwyl laasgenoemde dit nie geniet nie.

Ten spyte van die belang van hierdie onderskeid is daar geen definisie van ' $n$ dienskontrak in wetgewing te vinde nie en word die onderskeid hoofsaaklik deur middel van die gemene reg, in die vorm van die sogenaamde "multi-factor"-toets, bepaal. ${ }^{76}$ Die "multi-factor"-toets (wat baie in gemeen het met Suid-Afrika se dominante-indruk-toets soos hierbo bespreek), behels 'n reeks vrae oor verskeie aspekte van die verhouding tussen die organisasie en die werker. Hierdie vrae sluit onder andere in die mate van beheer wat die organisasie oor die werker het, die manier van vergoeding, of die werker haar eie gereedskap aanwend en onderhou en of die werk gedelegeer mag word. ${ }^{77}$ Die totale verhouding word dus ondersoek met die algemene indruk wat deurslaggewend is. ${ }^{78}$

Australiese federale wetgewing, die "Workplace Relations Legislation Amendment (Independent Contractors) Act" van 2006, het onlangs in werking getree om, aanvullend tot bogenoemde, die moontlike klassifisering van werknemers as onafhanklike kontrakteurs, waar 'n werkgewerwerknemer-verhouding inderdaad bestaan, te voorkom. Ingevolge artikel 900 van hierdie Wet kan die werkgewer, verantwoordelik vir so ' $n$ wanvoorstelling, ' $n$ boete opgelê word. ${ }^{79}$

In die praktyk, net soos in die geval van Suid-Afrika en Nederland, maak baie bordele in Victoria van "huisreëls" gebruik om werksomstandighede van sekswerkers te bepaal. Hierdie "huisreëls" hou verband met die skedulering en toewysing van sessies. Die bestuurder het die reg om aan te wys wanneer en hoe seksuele dienste deur sekswerkers verskaf moet word en die nie-nakoming van hierdie reëls het tot gevolg dat sessies verminder word, sekere sessies/tye ontoeganklik vir werkers gemaak word en werkers se name soms selfs van die rooster van die bordeel verwyder word. ${ }^{80}$ Skofte duur gewoonlik tussen 9 en 14 ure waartydens sekswerkers deur kliënte gekies kan word om seksuele dienste te verrig. Vroue werksaam by bordele rapporteer egter dat daar van hulle verwag word om die duurte van die hele skof by die perseel teenwoordig te wees. Werkers wat vroeër loop, sal of afgedank word, nie 'n ander skof gegee word nie of op 'n ander manier gepenaliseer word. ${ }^{81}$ Die werksomstandighede van vroue verbonde aan bordele word verder gewoonlik mondelings bepaal asook deur die algemene

75 Carabetta and Coleman "Employees no Longer: On the Federal Government's Proposals for Contractors" http://www.australianreview.net/digest/2005/06/carabetta.html 27 June 2005 (nageslaan Augustus 2009).

76 Stewart Stewart's Guide to Employment Law 2008 46-47.

77 Stewart 47.

78 Stewart 48.

79 Stewart 55.

80 Murray 200316 Australian Journal of Labour Law 22-23.

81 Murray 200316 Australian Journal of Labour Law 25-26. 
gebruike van die bedryf. Dit sluit in aanwysings oor kleredrag en uniforms en die betaling van gelde. ${ }^{82}$ Werkers mag verder versoek word om huur te betaal vir spesifieke kostuums indien die bordeel dit sou vereis. Een werker het gerapporteer dat sy verbied is om verder by 'n bordeel diens te verrig omrede sy haar hare afgeskeer het en die bordeel haar nie wou toelaat om met 'n geskeerde kop of 'n pruik diens te verrig nie. ${ }^{83}$

Nieteenstaande bogenoemde beheer wat deur bordeel-eienaars uitgeoefen word, word die meeste sekswerkers in Victoria ook steeds as onafhanklike kontrakteurs geag en geniet hulle nie dieselfde voordele as ander werknemers nie. ${ }^{84}$ Bordeel-eienaars poog om deur middel van die klassifisering van sekswerkers as onafhanklike kontrakteurs hul verantwoordelikhede vir hierdie werkers se regte en voordele te vermy. ${ }^{85}$ Juis as gevolg van die "multi-factor"-toets, wysig sommige bordeel-eienaars hul ooreenkomste met sekswerkers in so 'n mate dat laasgenoemde blyk onafhanklike kontrakteurs te wees. ${ }^{86}$

In die saak van Brooke and ALHMU - Miscellaneous Workers Division v Coppin Cafe Pty $L t d^{87}$ het die hof 'n aansoek van die onbillike ontslag van 'n sekswerker aangehoor. In die saak was die status van die sekswerkers egter nie in dispuut nie. 'n Bevel van skadevergoeding aan die sekswerker ten bedrae van $\$ 667$ is gemaak op grond van ontslag sonder geldige rede (wat ingevolge artikel 170DE (1) van die voormalige Industrial Relations Act van 1988 verbied is) asook die feit dat sy nie die nodige tydperk van kennis van ontslag gegee is nie (wat ingevolge artikel 170 DB (1) van die "Industrial Relations Act" van 1988 verlang is). ${ }^{88}$ Die sekswerker het egter nie heraanstelling verlang nie. ${ }^{89}$

Alhoewel sekswerkers verbonde aan bordele in Victoria se posisie met betrekking tot arbeidsregte ook wankelrig voorkom en dit blyk dat sekswerkers nie geredelik by howe aanklop vir die handhawing daarvan nie, ${ }^{90}$ is daar tog gesag as bevestiging van sekswerkers se status as dié van werknemers en nie van onafhanklike kontrakteurs nie. ${ }^{91}$ Die inwerkingtreding van die "Workplace Relations Legislation Amendment (Independent Contractors) Act" van 2006 kan bordeel-eienaars ook meer huiwerig laat om voort te gaan met die wanvoorstelling van sekswerkers as onafhanklike kontrakteurs in die toekoms.

\footnotetext{
Murray 200316 Australian Journal of Labour Law 26-27.

Murray 200316 Australian Journal of Labour Law 27.

Sullivan "Prostitution Law Reform in Australia. A Preliminary Evaluation" July 1999 18(3) Social Alternatives 10.

85 Sullivan July 1999 18(3) Social Alternatives 12.

86 Murray 51

87 [1996] IRCA 518.

88 Brooke and ALHMU - Miscellaneous Workers Division v Coppin Café Pty Ltd [1996] IRCA 518 par 10.

89 Brooke and ALHMU - Miscellaneous Workers Division v Coppin Café Pty Ltd supra 518 par 11

90 Murray 200316 Australian Journal of Labour Law 40

91 Brooke and ALHMU - Miscellaneous Workers Division v Coppin Café Pty Ltd supra 518.
} 


\section{SAMEVATTING EN SLOT}

Voorstanders van die dekriminalisering van die seksbedryf in Suid-Afrika argumenteer dikwels dat dekriminalisering verligting op die gebied van sekswerkers se toegang tot arbeidsregte sal meebring. ${ }^{92}$ Uit die vergelykende studie met Nederland en Victoria (Australië), waar sekswerk lank reeds as wettige beroep bedryf word, blyk dit egter dat sekswerkers se posisie tot beskerming deur arbeidswetgewing nie oornag met dekriminalisering verander het nie. Die meeste sekswerkers in hierdie lande word in die praktyk steeds as onafhanklike kontrakteurs bestempel en word juis om hierdie rede weereens van arbeidswetgewing uitgesluit. Relevante hofgesag op dié gebied in beide Nederland en Victoria (Australië) is wel aanduidend daarvan dat die verhouding tussen bordeel-eienaar en sekswerkers inderdaad een van werkgewer-werknemer is en dat sekswerkers wel geregtig is op die beskerming van hul bestaande arbeidswetgewing.

Wat Suid-Afrika egter betref, is die "Kylie-saak" tans aanduidend van die afwesigheid van arbeidsregte in die seksbedryf. Dekriminalisering sal ons in lyn met lande soos Nederland en Victoria (Australië) bring en dus 'n meer suksesvolle weg baan vir sekswerkers soos "Kylie" wat onbillike arbeidspraktyke in die uitoefening van hul beroep ervaar en bereid is om hulself tot die howe te wend vir die handhawing van hul arbeidsregte. Die vrees vir die stigma as sekswerker kan egter steeds baie sekswerkers verhoed om hierdie roete te volg. ${ }^{93}$ Een werker in die seksbedryf van Australië het dit soos volg gestel: ${ }^{94}$

"There is no WorkCover, there is none of that stuff. And the price we have to pay if we are to get that is extremely high in a society that still does not accept sex workers as equal. Because the price to get that stuff is revealing our true identity. And most of the girls don't want to do that. The reason why we don't want to do that is basically because none of us want to be tagged in broader society as hookers."

Alhoewel die dekriminalisering van die seksbedryf in Suid-Afrika dus 'n stap in die regte rigting is om toegang tot arbeidsregte te bereik kan daar verwag word dat sekswerkers nie onmiddellik daarna as werknemers geag en hanteer sal word nie. Die integrasie van sekswerkers tot die wettige arbeidsmag kan 'n langdurige proses wees waarvan die "wanvoorstelling" van sekswerkers as onafhanklike kontrakteurs en hul huiwering om hul tot die howe te wend waarskynlik as die eerste struikelblokke sal dien. Eers met die oorbrugging daárvan wag die nog meer ingewikkelde taak, naamlik die toepassing van bestaande arbeidswetgewing op 'n nuwe en baie unieke industrie.

\footnotetext{
Arnott and Alexander 16 Augustus 2001 Weekly Mail \& Guardian 22.

93 Inglis "Expanding International and National Protections Against Trafficking for Forced Labor using a Human Rights Framework" 20017 Buffalo Human Rights Law Review 89.

94 Murray 200316 Australian Journal of Labour Law 45.
} 